\title{
MENELISIK DINAMIKA RADIKALISME GEN Z PEREMPUAN DI FACEBOOK
}

\author{
Eko Saputra \\ Universitas Islam Negeri Sunan Kalijaga Yogyakarta, Indonesia \\ E-mail: eko322590@gmail.com
}

\begin{abstract}
Nowadays, the proliferation of radicalization among the so-called Generation $Z$ in the online space shows an alarming phenomenon. This article is to explore how online media is used by a woman of generation Z, Nurdhania, to access ideological propaganda of the Islamic State in Iraq and Syria (ISIS). The questions are how was the propaganda embedded in Nurdhania's mind? How big are the Nurdhania's commitment, involvement, and struggle in supporting ISIS? To answer these questions, this research used the method of ethnography, through the internet, of blogs and social media that belong to Nurdhania, and conducted an interview with one of her relatives in Yogyakarta. This article argues that Nurdhania was exposed to the ideology of ISIS because of (1) her confusion with the uncertainty of the future; (2) a 'moral panic' she had experienced; and (3) the Islamic State highlighted as the most ideal state system.
\end{abstract}

Keywords: Online media; radical women; ISIS ideology; Gen Z.

\section{Pendahuluan}

Ideologi ekstremis-jihadis kini mempengaruhi umat Muslim lewat berbagai saluran, baik eksternal maupun internal. ${ }^{1}$ Dalam lingkup internal, pengaruh ideologi ekstremis-jihadis datang dari

\footnotetext{
${ }^{1}$ Evan Tighe, "Trust in Allah, But Tie Your Camel: The Effects of Radicalized Schooling and State Security on Islamic Terrorism in the Middle East" (Disertasi--University of Georgia, Athens, 2011); Chris Zambelis, "Is there a Nexus between Torture and Radicalization?”, Terrorism Monitor, Vol. 6, No. 13 (2008), 26; dan James Gow et al. (eds.), Militancy and Violence in West Africa: Religion, Politics, and Radicalisation (London: Routledge, 2013), 181-235.
} 
hubungan keluarga, perkawinan, kondisi kemiskinan, dan jaringan intelektual antarkelompok jihadis. ${ }^{2}$ Sementara itu, pada lingkup eksternal, pengaruh ideologi tersebut berpenetrasi melalui literatur keislaman; ${ }^{3}$ kohesi sosial, identitas dan solidaritas, dan lingkungan sosial; ${ }^{4}$ dan distribusi jaringan terorisme dan pendidikan ekstremisme. $^{5}$

Beberapa studi di atas tampaknya kurang memperhatikan keterlibatan perempuan dalam aktivitas kelompok jihadis. Hal tersebut dapat dimaklumi, mengingat nuansa patriarkis begitu kuat dalam tradisi kelompok jihadis, di mana peran perempuan hanya sebatas mendidik anak, mengurus dapur, dan melayani laki-laki. Apabila perempuan ikut terlibat dalam aktivitas jihad, dikhawatirkan akan mengancam kelangsungan generasi jihadis. ${ }^{6}$ Oleh

2 Noor Huda Ismail, "The Role of Kinship in Indonesia's Jemaah Islamiya”, Terrorism Monitor, Vol. 4, No. 11 (2006); Michael King dan Donald M. Taylor, "The Radicalization of Homegrown Jihadists: A Review of Theoretical Models and Social Psychological Evidence", Terrorism and Political Violence, Vol. 23, No. 4 (2011); Laporan IPAC No. 35, "Mother to Bombers: The Evolution of Indonesia Woman Extremists” (2017); IPAC No. 51, “The Surabaya Bombing's and the Future of ISIS in Indonesia" (2018); kondisi kemiskinan disebutkan oleh James A. Piazza, "Poverty, Minority Economic Discrimination, and Domestic Terrorism", Journal of Peace Research, Vol. 48, No. 3 (2011), 339-357; Anissa Hélie, "The US Occupation and Rising Religious Extremism: The Double Threat to Women in Iraq", Znet, 24 Juni 2005, http:/ /www.zcommunications.org/the-u-soccupation-and-rising-religious-extremism-by-anissa-h-lie.

3 Munirul Ikhwan, "Produksi Wacana Islam di Indonesia: Revitalisasi Islam Publik dan Politik Muslim", dalam Noorhaidi Hasan et al., Literatur Keisalaman Generasi Milenial: Transmisi, Apropriasi, dan Kontestasi (Yogyakarta: UIN Sunan Kalijaga Perss 2018), 109-142; Noorhaidi Hasan, "Menuju Islamisme Populer", dalam Ibid., 1-29.

${ }^{4}$ Rosalie Smit, "Defining Professionalism in anti-Islamic Radicalism Policies", Working Research Paper (Working in the Front-line of Society Amsterdam, 2009).

${ }^{5}$ Zuly Qodir, "Gerakan Salafi Radikal dalam Konteks Islam Indonesia: Tinjauan Sejarah”, Islamica: Jurnal Studi Keislaman, Vol. 3, No. 1 (2008), 1-15; Laporan ICG (International Crisis Group) No. 83, "Indonesia Backgrounder: Why Salafism and Terrorism Mostly Adon't Mix" (2004), 1-63; IPAC No. 47, "Managing Indoneaia's Pro-ISIS Deportees" (2018), 1-13; IPAC No. 13, "The Evolution of ISIS in Indonesia" (2014), 1-25.

6 Amin Saikal, "Women and Jihad: Combating Violent Extremism and Developing New Approaches to Conflict Resolution in the Greater Middle East", Journal of Muslim Minority Affairs, Vol. 36, No. 3 (2016), 313-322; Lahoud Nelly, "The Neglected Sex: The Jihadis' Exclusion of Women From Jihad", Terrorism and Political Violence, Vol. 26, No. 5 (2014), 780-802. 
karenanya, perempuan tidak diwajibkan berperan dalam aksi-aksi jihad dan lebih ditempatkan di belakang layar untuk mendidik anak-anak dan mengurus urusan domestik.

Namun demikian, kasus keterlibatan perempuan dalam aktivitas jihad tidak lantas berarti tidak ada. Beberapa studi lainnya telah menunjukkan beberapa fakta bahwa kini perempuan mulai memiliki tempat dalam aktivitas kelompok jihadis, bahkan sebagai aktor terorisme. Pertama, perempuan dijadikan sebagai strategi baru oleh kelompok jihadis dalam melancarkan aksi terorisme. ${ }^{7}$ Kedua, perempuan dijadikan sebagai penguat jaringan kelompok jihadis melalui hubungan pernikahan. ${ }^{8}$ Ketiga, bergabungnya para Tenaga Kerja Wanita (TKW) Indonesia di Hong Kong dengan kelompok Islamic State in Iraq and Syria (ISIS). ${ }^{9}$ Keempat, dukungan normatif perempuan dalam internal keluarga untuk bergabung dengan kelompok jihadis. ${ }^{10}$ Kelima, evolusi perempuan dalam tindakan terorisme di Indonesia mendukung ISIS. ${ }^{11}$ Keenam, keterlibatan perempuan Salafi-jihadis yang termotivasi dan bergabung dengan kelompok ekstremis. ${ }^{12}$ Ketujuh, sebagian perempuan berada dalam pencarian keagamaan. ${ }^{13}$

Selain itu, beberapa studi tentang perempuan ekstremis-jihadis di atas tampak lebih fokus pada persebaran ideologi dan keterlibatan perempuan di dalamnya melalui ruang offline. Studi tersebut kurang memperhatikan bagaimana ideologi ekstremisjihadis dikonsumsi melalui literatur dunia virtual (online literature), terutama oleh Generasi Z (Gen Z). Hadirnya media baru berupa media sosial (medsos) seperti Facebook, Twitter, YouTube, dan Instagram di era Gen $Z$ memberikan penjelasan yang menarik tentang fenomena propaganda ideologi ekstremis-jihadis. Perlu digaris-bawahi bahwa media memiliki kekuatan superior dalam hal

\footnotetext{
7 IPAC, "The Surabaya Bombing's".

8 Ismail, "The Role of Kinship".

9 IPAC No. 39, "The Radicalisation of Indonesian Woman Workers in Hong Kong" (2017), 1-19.

${ }^{10}$ Ismail, "The Role of Kinship".

11 IPAC, "Mother to Bombers".

12 Katharina Von Knop, "The Female Jihad: Al Qaeda's Women", Studies in Conflict \& Terrorism, Vol. 30, No. 5 (2017), 397-414.

${ }^{13}$ Nava Nuraniyah, "Not Just Brainwashed: Understanding the Radicalization of Indonesian Female Supporters of the Islamic State", Terrorism and Political Violence, Vol. 30, No. 6 (2018).
} 
komunikasi. ${ }^{14}$ Media memiliki kekuatan memproduksi wacana atau pesan yang membentuk sebuah kebenaran, walaupun sering kali sebuah pesan tidaklah benar. ${ }^{15}$ Media memiliki peran penting dalam mengkonstruksi pikiran (mind) seseorang, tidak terkecuali Gen $Z$ yang suka 'berimigrasi' ke dunia virtual.

Sebagai upaya mengisi kekurangan tersebut, artikel ini akan membahas media sosial (medsos) sebagai salah satu media atau tempat yang efektif untuk menaburkan benih-benih baru ekstremisme. Secara spesifik, artikel ini membahas pengaruh ideologi ekstremisme ISIS di Facebook; tentang bagaimana modus penyebaran dan bagaimana Gen Z perempuan menerimanya. Artikel ini merujuk pada salah satu akun Facebook penyebar paham ekstremisme ISIS, yaitu Diary of $A$ Mubajirah, dengan fokus pada salah seorang remaja atau Gen $Z$ perempuan, Nurdhania, yang mengaku terpapar ideologi ISIS lewat akun tersebut hingga memutuskan menjadi foreign fighter ISIS di Syria selama satu tahun dan 10 bulan. ${ }^{16}$ Untuk kepentingan itu, penulis melakukan etnografi online pada blog pribadi dan akun medsos Nurdhania lainnya, dan portal ruangobrol.id. Media tersebut menjadi sumber data penulis untuk memperoleh data penting tentang Nurdhania, selain wawancara dengan sepupu laki-lakinya. ${ }^{17}$ Artikel ini menemukan bahwa kehadiran medsos memiliki peran yang sangat signifikan bagi keberhasilan diseminasi ideologi ekstremisme ISIS di kalangan Gen Z.

\section{Gen Z, Medsos, dan Fenomena Islam Virtual}

Gen $Z$ adalah generasi yang lahir sesudah generasi milenial. ${ }^{18}$ Gen $\mathrm{Z}$ disebut sebagai generasi keempat setelah Baby Boomers (1946-1964), Generasi X (1965-1987), dan Generasi Y (milenial/ 1982-1995). ${ }^{19}$ Sementara Gen Z lahir antara tahun 1995 sampai

\footnotetext{
${ }^{14}$ Marshall McLuhan, Understanding Media (New York: McGraw-Hill, 1965).

15 Lihat booklet Pidato Pengukuhan Guru Besar Iswandi Syahputra, Hoaks dan Spiral Kebencian di Media Sosial (Yogyakarta: UINSunan Kalijaga Yogyakarta, 2019), 1-10.

16 https://www.ruangobrol.id/2019/11/21/ulasan/analisa/pengalaman-returne es-kena-doktrinisasi-kelompok-ekstrimis/. Diakses pada 10 Juli 2019.

${ }_{17}$ M. Raihan, adik sepupu Nurdhania (anak pamannya), adalah satu di antara keluarga besar Nurdhania yang ikut pergi ke Syria sebagai simpatisan ISIS.

18 Emma Broadbent, Generation Z: Global Citizenship Survey (London: Varkey Fundation, 2017), 3.

${ }^{19}$ Lihat https://youtu.be/DJ7lxI4YcfY. Diakses pada 12 Juli 2019.
} 
$2001 .^{20}$ Pendapat lain menyebutkan bahwa Gen Z lahir antara tahun 1995 sampai 2000, ${ }^{21}$ yaitu generasi pertama yang melihat abad ke-22.22 Saat ini usia mereka mencapai 17 hingga 24 tahun. ${ }^{23}$ Sebagian dari mereka duduk di bangku Sekolah Menengah Atas (SMA), dan yang paling banyak berada di jenjang Perguruan Tinggi (PT). ${ }^{24}$

Gen Z lahir di era di mana teknologi digital mengalami perkembangan yang sangat pesat, terutama saat medsos menjadi tren gaya hidup kalangan anak muda global. ${ }^{25}$ Lahirnya Gen $\mathrm{Z}$ di era ini membuat kehidupan mereka tidak bisa dipisahkan dari gadget, internet, termasuk medsos. Dunia digital sudah menjadi konsumsi rutin mereka sehari-hari. Tidak berlebihan jika ciri dan karakteristik Gen Z ditunjukkan oleh beberapa hal berikut:

Pertama, Gen Z dibekali dengan 'gen digital' sedari lahir. Tanpa belajar pun, potensi mereka untuk mengoperasikan internet dibilang sangat baik, mengalahkan generasi-generasi sebelumnya. Tidak bisa disangkal, generasi yang lahir pada tahun 1995 ke atas memiliki peluang akses internet yang begitu besar. Pada tahun 2019 ini, mereka berada di usia tidak lebih dari 23-24 tahun. Kedua, Gen $\mathrm{Z}$ sangat suka menjelajahi dunia internet, termasuk medsos, seperti Facebook, Twitter, Instagram, Line, Telegram, YouTube, dan lainnya. Melalui medsos, mereka sangat leluasa mencurahkan ekspresi tentang apa yang dipikirkan dan dirasakan. Ketiga, Gen Z lebih banyak belajar dengan menggunakan media digital, karena teknologi digital lahir di era mereka dan diciptakan khusus untuk mereka. Keempat, Gen Z dikenal lebih mandiri dari generasi sebelumnya. Ketika mereka terbentur dengan sesuatu yang tidak mereka ketahui, mereka menggunakan gadgetnya untuk googling. Belajar melalui internet membuat mereka lebih mandiri dengan berbagai keputusan yang akan mereka lakukan. Mereka tidak banyak memerlukan masukan-masukan ataupun pertimbangan-

\footnotetext{
${ }^{20}$ Ibid.

21 Yunita Faela Nisa, "Generasi Z: Generasi yang Galau", dalam Didin Syafruddin dan Ismatu Ropi (eds.), Generasi Z: Kegalauan Identitas Keagamaan (Jakarta: PPIM-UIN Jakarta, 2018), 3.

22 Broadbent, Generation Z, 45-52.

${ }^{23}$ Nisa, "Generasi Z", 3.

${ }^{24}$ Suhadi, "Menu Bacaan Pendidikan Agama Islam", dalam Hasan et al., Literatur Keislaman, 29-62.

${ }^{25}$ Lihat https:/ / youtu.be/DJ7lxI4YcfY. Diakses pada 12 Juli 2019.
} 
pertimbangan dari orang lain, termasuk orang tua mereka. Mereka cenderung lebih mengetahui permasalahan mereka sendiri. Kelima, Gen Z cenderung kurang aktif dalam komunikasi verbal; lebih egosentris, individualis, dan instan, sehinga tidak jarang sesuatu yang mereka persepsikan berujung kekeliruan.

Data wic.org dan wic.org mencatat $44 \%$ Gen Z memeriksa gadgetnya sekali dalam setiap satu jam. Hal ini sejalan dengan data Wikipedia bahwa Gen Z tidak dapat dipisahkan dari internet. Penelitian The Goldman Sachs menyatakan hampir setengah dari Gen $\mathrm{Z}$ terhubung secara online di media digital selama 10 menit dalam sehari, bahkan bisa lebih. ${ }^{26}$ Kompas.com menyebut pengguna medsos Indonesia berada di pringkat ke-6 dunia dengan populasi netter mencapai 83.7 juta orang pada 2014. ${ }^{27}$ Berdasarkan data tersebut, ketertarikan Gen Z terhadap dunia maya sangatlah tinggi, dan menjadi gaya hidup mereka sebagai anak muda virtual. Mereka mengunakan medsos untuk merespons isu-isu yang sedang updated, mencari kesenangan, relasi pertemanan, destinasi wisata, bahkan tempat belajar untuk memperoleh pengetahuan agama.

Di Indonesia, dalam lima tahun terakhir, narasi agama menjadi keyword yang banyak dicari oleh Gen Z, seperti istilah "kafir", "Yahudi Zionis", "Indonesia thogut", "takbir", "tauhid", "khilafah", dan "jihad". Menurut Andang Sunarto dan Dirga Maulana, pencarian keyword tersebut merupakan langkah awal terperangkapnya Gen $\mathrm{Z}$ dalam pusaran radikalisme. ${ }^{28}$ Bagi mereka yang awam soal agama, dunia virtual menjadi sumber utama dalam mendapatkan pengetahuan agama. Menurut Campbell, medsos di ruang virtual membentuk dan dibentuk oleh praktik keagamaan. "Agama online" menunjukan bagaimana internet menawarkan lanskap kehidupan sosial baru untuk 'pencitraan' masyarakat spiritual. ${ }^{29}$ Oleh karena itu, sering kali Gen Z menggunakan

\footnotetext{
${ }^{26}$ Lihat https://id.m.wikipedia.org/wiki/GenerasiZ. Diakses pada 13 Juli 2019.

27 Lihat https://www.google.com/amp/s/amp.kompas.com/tekno/read/2014 /11/24/07430087/Pengguna.Internet.Indonesia.Nomor.Enam.Dunia.

28 Andang Sunarto, "Dampak Penyebaran Ideologi Ultrakonservatif di Media Sosial”, Nuansa, Vol. 11, No. 2 (2017); Dirga Maulana, Situs-situs Islam: Konstestasi Narasi Radikal dan Moderat, Vol. 1, No. 3 (Jakarta: PPIM UIN Syarif Hidayatullah Jakarta, 2018), 4.

${ }^{29}$ Lihat pengantar Heidi A. Campbell (ed.), Digital Religion: Understanding Religious Practice in New Media Worlds (London: Routledge, 2013), 3-4.
} 
internet sebagai jalan instan untuk mendapatkan pengetahuan agama.

Internet membentuk praktik-praktik masyarakat baru, ${ }^{30}$ religusitas baru, ${ }^{31}$ di mana masyarakat menjalankan praktik keagamaan online. Namun, internet juga memungkinkan terjadinya 'duplikasi' (penggandaan) agama yang saling 'tumpang tindih', yaitu agama yang diajarkan dalam realitas masyarakat dengan agama yang dikonsumsi di ruang online, ${ }^{32}$ terutama dalam arus pos-Islamisme yang banyak memperkenalkan kemasan agama dalam bentuk literatur online. ${ }^{33}$ Situasi ini membuat Gen Z mulai meninggalkan literatur yang dikonsumsi generasi sebelumnya, yang berbentuk buku-buku, majalah, dan novel Islami. ${ }^{34}$ Gen $Z$ lebih akrab bersinggungan dengan Islam di dunia maya dari pada di buku, majalah, dan novel. Sebagai generasi digital native,,$^{35}$ yang mandiri dalam meyelesaikan persoalan hidup dan memiliki ketertarikan dengan dunia virtual, mereka meninggalkan literatur offline ke online.

Situasi ini digunakan oleh kelompok ekstremis, seperti ISIS, sebagai ruang obrolan dan rekrutmen penjuang (fighter) baru. Kelompok tersebut menggiring Gen $Z$ ke pusaran ideologi jihad, terutama mereka yang kondisi psikologisnya tidak stabil, seperti ditingal pacar, masalah pertemanan, kekerasan rumah tangga, atau perceraian orang tua, di mana kondisi tersebut memudahkan kelompok ekstremis untuk melakukan pencucian pikiran. ${ }^{36}$ Namun demikian, penyebaran ideologi ISIS tentang negara Islam (Islamic

\footnotetext{
${ }^{30}$ Raymond Williams, Television: Technology and Cultural Form. London: Routledge, 2003).

31 Robert Glenn Howard, "Enacting a Virtual 'Ekklesia': Online Christian Fundamentalism as Vernacular Religion", New Media \& Society, Vol. 12, No. 5 (2010), 729-744.

32 G. Young, "Reading and Praying Online: The Continuity of Religion Online and Online Religion in Internet Christianity", dalam L. Dawson and D. Cowan (eds.), Religion Online: Finding Faith on the Internet (New York: Routledge, 2004), 93-106.

33 Noorhaidi Hasan, "Gagalnya Jihadisme di Kalangan Generasi Milenial", dalam Hasan et al., Literatur Keislaman, 270.

${ }^{34}$ Ikhwan, "Produksi Wacana Islam".

35 Lucy Pujasari Supratman, "Penggunaan Media Sosial oleh Digital Native", Ilmu Komonikasi, Vol. 15, No. 1 (2018), 49.

36 Lihat https://www.ruangobrol.id/2019/11/27/fenomena/perdamaian/retur nees-juga-pernah-galau/.
} 
state), tauhid, hijrah ke Syria, sistem demokrasi täghūt, dan lain sebagainya, membutuhkan proses yang tidak cepat. ${ }^{37}$

\section{Diary of A Muhajirah}

Diary of $A$ Mubajirah adalah nama yang dipakai oleh sebuah akun Facebook, yang giat memproduksi kebenaran ideologi ISIS, di tengah berbagai informasi lain yang menyebut ISIS sesat, ekstremis, pembunuh, dan teroris. ${ }^{38}$ Akun tersebut menjadi portal penyebaran ideologi dan pengetahun tentang ISIS, sekaligus sebagai media yang terbilang efektif merekrut simpatisan atau pejuang ISIS, dan mengajak mereka untuk hijrah ke Syria.

\section{Gambar 1:}

Akun Facebook Diary of A Mubajiriah

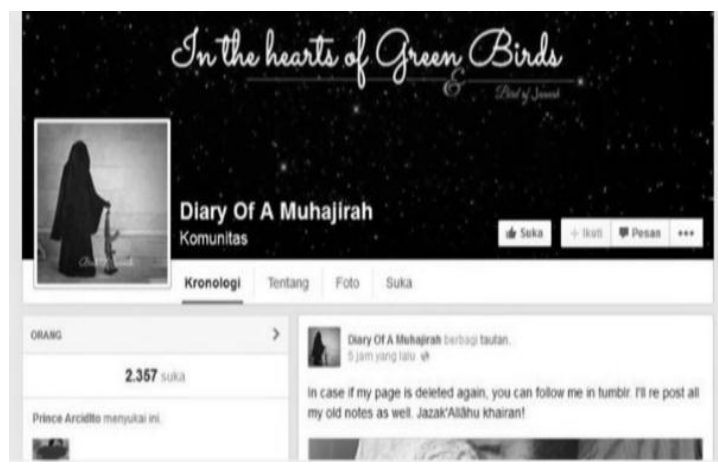

Akun tersebut menekankan pada 10 prinsip atau pandangan. Pertama, negara Islam. Kedua, tidak ada riba di dalam negara Islam. Ketiga, negara Islam bebas berdakwah kepada siapa saja. Keempat, kalimat "Ittaqü Alläb" (bertakwalah kepada Allah) sebagai nasihat, bukan vonis ataupun hujatan. Kelima, jika Malaysia dikatakan "truly Asia", maka negara Islam benar-benar global (non-nasionalisme atau 'ashäbijah). Keenam, siapapun yang bertemu di jalan dengan kita, maka dia mengucapkan salam kepada kita dengan sebutan ikhwān kepada ikhwān, akhwät kepada akbwät. Ketujuh, jangan terkejut bila ada makanan di depan pintu rumah. Kedelapan, tidak ada pergaulan bebas, alkohol, dan pornografi. Kesembilan, semua

\footnotetext{
${ }^{37}$ M. Raihan Rafisanjani (sepupu Nurdhania), Wawancara, di Yogyakarta.

${ }^{38}$ Lihat https:/ / youtu.be/4Cm-b9lkyec. Diakses pada 13 Juli 2019.
} 
perempuan berbusana shar'ī. Kesepuluh, kematian bisa datang kapan saja, tetapi semua orang di sini "tersenyum". ${ }^{39}$

Setiap penjelasan oleh akun Diary of $A$ Mubajirah selalu didasarkan pada al-Qur'ān dan Hadīth. ${ }^{40}$ Beberapa penjelasan juga didukung oleh bukti-bukti berupa gambar, video, hingga testimoni orang yang sudah bergabung. ${ }^{41}$ Hal tersebut tentu akan mudah menarik perhatian orang, dalam hal ini pengguna Facebook, terutama mereka yang sedang haus akan pemahaman keagamaan. Secara umum, penjelasan tersebut dilakukan untuk menanamkan kepercayaan bahwa ISIS tidak seburuk apa yang selama ini dicitrakan media.

Selain itu, Diary of $A$ Mubajirah juga memperkenalkan janji jaminan hidup bersama ISIS, sebelum kemudian mengajak berijhad dan hijrah ke Syria. Jaminan ini adalah seperti apa yang dikatakan oleh Abū Bakr al-Baghdādī, pemimpin ISIS, di YouTube pada 29 Juni 2014, bahwa khilafah Islam (ISIS) berdasarkan pada manhaj khiläfah nubunwah Islämìyab; mencukupi kebutuhan hidup, seperti kesehatan, pekerjaan, tempat tinggal, pendidikan, dan ekonomi. ${ }^{42}$ Mereka yang telah bergabung dan berhijrah ke Syria berangkat dari keyakinan akan kebenaran beberapa fakta ISIS yang coba diajukan oleh Diary of A Mubajirab: ${ }^{43}$ (1) tidak semua mujahid Islamic State (IS) adalah tentara yang berperang di lapangan. IS memiliki mujahid yang berprofesi sebagai dokter, guru, insinyur, dan lainnya; (2) mujahid di IS tidak harus berperang, tetapi juga bisa melakukan amal-amal sosial; (3) para mujahid berasal dari berbagai negara dan latar belakang yang beragam, berbicara dalam bahasa "haqq" (kebenaran); (4) mereka banyak mencintai kucing; (5) jihad adalah istri pertama mereka, dan AK-47 adalah kekasih mereka; (6) mujahid yang pandai memasak, yaitu kaum perempuan, adalah para syahid; (7) "Saleel Sawarim" dan "Enter the Truth" adalah acara favorit para mujahid IS; (8) jika ingin membuat para mujahid IS

\footnotetext{
39 Lihat https://m.facebook.com/groups/251751038294937?view=permalink \&id=538586862944685. Diakses pada 10 Juli 2019.

${ }^{40}$ Lihat https://www.ruangobrol.id/ulasan/analisa/pengalaman-returnees-kenadoktrinisasi-kelompok-ekstrimis/. Diakses pada 13 Juli 2019.

41 Lihat https://www.ruangobrol.id/2019/11/21/ulasan/analisa/pengalamanreturnees-kena-doktrinisasi-kelompok-ekstrimis/. Diakses pada 10 Juli 2019.

42 IPAC No. 47, "Managing Indonesia's Pro-ISIS Deportees” (2018), 1-13.

${ }^{43}$ Lihat https://m.facebook.com/groups/251751038294937?view=permalink\& id $=538586862944685$. Diakses pada 10 Juli 2019.
} 
tertawa, maka ancamlah mereka dengan kematian; (9) berada di dalam perut burung hijau (karunia bagi syahid); (10) mereka terobsesi dengan selai yang terbuat dari cokelat dan hazelnut.

\section{Nurdhania: Kepanikan Moral Gen Z}

Nurdhana Khaira Dhania, atau yang sering disapa Nurdhania adalah salah seorang perempuan Gen Z yang terpapar ideologi ISIS. Sebagai Gen Z, ia sangat akrab dengan teknologi digital dan pengguna aktif medsos, baik Facebook, Twitter, Instagram, atau blog. Melalui media Facebook, Nurdhania berjumpa dengan akun Diary of $A$ Mubajirah. Akun tersebut adalah titik awal, yang kemudian membuat ia hijrah ke Syria bergabung bersama para pejuang ISIS. Awalnya ia hanya menyukai (like) unggahan akun tersebut, dan membaca beberapa catatan hijrah para perempuan Muslim dari berbagai negara yang bergabung bersama ISIS. Setelah ia menyukai unggahan tersebut, ia kemudian disapa, diajak kenalan, diajak berdiskusi dan bertukar pandangan tentang negara Islam. Proses doktrinasi ini, menurut Nurdhania, membutuhkan waktu yang tidak cepat. Diperlukan proses yang cukup lama hingga akun tersebut mampu meyakinkan Nurdhania.

Perbincangan di antara mereka semakin akrab. Secara perlahan akun Diary of $A$ Mubajirah mulai mengenalkan bagaimana seharusnya menjadi sosok Muslimah yang baik, yaitu Muslimah yang mematuhi ajaran agama, dan bagaimana menjadi seorang istri yang baik kelak. ${ }^{44}$ Pada tahap selanjutnya, ia diperkenalkan dengan dalil-dalil al-Qur'ān dan Hadīth mengenai cerita kemuliaan orangorang yang hijrah; kewajiban patuh kepada pemimpin negara Islam; sistem demokrasi yang täghüt, dan Pancasila yang syirik. ${ }^{45}$ Penjelasan tahap berikutnya beralih pada hukum menegakkan jihad. Akun tersebut mengatakan mati yang paling baik adalah mati berperang melawan musuh Islam (orang-orang kafir, terutama Yahudi dan Barat). Pada akhirnya, penjelasan sampai pada kewajiban hukum seorang Muslim hijrah ke Syria.

\footnotetext{
44 Lihat https://m.facebook.com/groups/251751038294937?view=permalink\& id $=538586862944685$. Diakses pada 13 Juli 2019.

45 Lihat https://www.ruangobrol.id/2019/11/27/fenomena/perdamaian/retur nees-juga-pernah-galau/; dan https://www.ruangobrol.id/2019/11/21/ulasan/ analisa/pengalaman-returnees-kena-doktrinisasi-kelompok-ekstrimis/.

Keduanya diakses pada 13 Juli 2019.
} 
Narasi-narasi yang diberikan oleh akun di atas, sebagaimana diakui, membuat Nurdhania galau dan khawatir. Ia mulai berpikir bila dirinya tidak hijrah ke Syria akan mati dalam keadaan jahiliyah, dan selamanya tidak akan mencium wanginya surga. ${ }^{46}$ Demikian pula, tradisi samínā wa ata'nà semakin membuat Nurdhania khawatir jika dirinya tidak akan mendapatkan rida Allah dan mati tidak membawa ketakwaan. ${ }^{47}$

'Kegalauan' Nurdhania tersebut tak lain adalah fenomena moral panic yang dialami oleh Gen Z Indonesia. Berdasarkan laman survei Mark Plus Insight bertajuk Youth Monitoring pada 2015, ditemukan lebih dari 6.798 responden anak muda di 18 kota di Indonesia mengalami kegalauan dikarenakan ketidakpastian target yang ingin dicapai. Jika target yang ditetapkan oleh anak muda tidak terpenuhi, maka akan menjadi beban dalam hidup mereka. Hal senada dikemukakan oleh Nisa bahwa kecemasan yang membuat buruk kondisi anak muda ialah ketika mereka tidak bisa menyelesaikan tugas dengan baik. ${ }^{48}$ Sementara itu, hasil survei yang dilakukan oleh Broadbent menunjukkan bahwa Gen Z Indonesia menjadikan agama sebagai tempat pelarian kecemasan. ${ }^{49}$ Agama menjadi sumber energi ketenangan, dan yang paling penting lagi ialah kepada siapa ia memutuskan akan berteman. Dari 20 negara yang disurvei oleh Broadbent, Indonesia berada pada peringkat kedua setelah Nigeria yang menempatkan agama sebagai pelindung kecemasan. $^{50}$

Demikian pula penelitian lain yang dilakukan Nisa menunjukkan bahwa kecemasan Gen Z terjadi ketika mereka tidak bisa menetapkan pencapaian standar hidupnya berdarkan kesuksesan orang lain. ${ }^{51}$ Di samping itu, standar kesuksesan yang ditetapkan oleh anak muda selalu berubah-ubah, karena ia mengikuti cara orang lain dalam mencapai keberhasilan. Sifat ikutikutan tersebut membuat mereka tidak mempunyai pendirian yang

\footnotetext{
46 Lihat https://shiningsooul.wordpress.com/2019/07/02/warna-warni-hidup/.

47 https://www.ruangobrol.id/2019/11/21/ulasan/analisa/pengalaman-returne es-kena-doktrinisasi-kelompok-ekstrimis/. Diakses pada 13 Juli 2019.

${ }^{48}$ Nisa, "Generasi Z".

${ }^{49}$ Broadbent, Generation Z, 50.

${ }^{50}$ Ibid., 50-51.

${ }^{51}$ Nisa, "Generasi Z".
} 
tegas dan tanpa tujuan yang jelas. Ketidakkonsistenan ini membuat anak muda masuk ke dalam kegalauan yang berkepanjangan.

Nurhdania ialah anak muda yang termasuk dalam golongan di atas. Rasa ketakutan yang berkepanjangan dalam diri Nurdhania menjadi beban dalam hidupnya. Hal ini berdasarkan pengakuannya sendiri yang ditulis dalam blog pribadinya. ${ }^{52}$ Pendiriannya yang masih labil dan mudah terpengaruh dijadikan kesempatan oleh kelompok ekstremis ISIS untuk merekrutnya sebagai pejuang baru. Penjelasan yang diambilkan dari al-Qur'ān dan Hadīth dan narasinarasi antibudaya Barat sekuler yang sering diajukan oleh ISIS membuat ia semakin dilema hingga akhirnya ia masuk ke dalam perangkap propaganda ideologi ISIS. Ditambah lagi, para syahid umat Islam yang berguguran dalam berperang di jalan Allah menambah keyakinan Nurdhania untuk bergabung dengan ISIS dan hijrah ke Syria. ${ }^{53}$

Dalam keadaan seperti ini, Nurdhania sadar akan posisinya sebagai generasi penerus umat Muslim yang akan datang, sehingga bergabung dengan kelompok ISIS dirasa sebagai keputusan yang tepat. Merujuk Bayat dan Herrera, anak muda adalah pembangun masa depan elit penguasa. Anak muda "distigmatisasi" sebagai agen yang rentan terhadap penyimpangan dan radikalisme. Anak muda dapat dijadikan sebagai alat politik massa dan moralitas otoritas (penguasa). Anak muda juga sebagai produsen sekaligus konsumen (penikmat). ${ }^{54}$ Anak muda sebagai produsen berarti ia sebagai pejuang untuk mengatur mobilitas pergerakan dunia, dan anak muda sebagai konsumen berarti penikmat hasil jerih payah perjuangannya. "Anak muda" adalah atribut yang disandarkan pada kondisi biologis seseorang yang membawa waktu dan karakteristik sosiopsikologis yang terkait dengan budaya. ${ }^{55}$ Masa muda adalah masa transisi antara masa kanak-kanak (childhood), yang polos dan butuh perlindungan, dan masa dewasa (adulthood) yang ditandai dengan rasa tanggung jawab yang tinggi, dan sepenuhnya mandiri

\footnotetext{
52 https://shiningsooul.wordpress.com/2019/07/02/warna-warni-hidup/.

53 https://www.ruangobrol.id/2019/11/21/ulasan/analisa/pengalaman-returne es-kena-doktrinisasi-kelompok-ekstrimis/. Diakses pada 13 Juli 2019.

${ }^{54}$ Lihat pengantar "Being Young and Muslim in Neoliberal Times" dalam Linda Herrera dan Asef Bayat (eds.), Being Young and Muslim: New Cultural Politics in the Global South and North (Oxford: Oxford University Press, 2010), 3.

55 Ibid., 6.
} 
Selanjutnya, Bayat dan Herrera mengatakan anak muda menunjukkan pikiran untuk terjun ke dunia kerja, tingkat kemandirian membuat pilihan, dan ekspresi ide-ide otonom. ${ }^{56}$ Ketika anak muda berpikir untuk membuat keputusan secara madiri, pada titik itulah terjadi dilema atau kegalauan tentang memutuskan 'siapa diri saya' sesungguhnya, 'ke mana diri saya' akan dibawa, dan 'seperti apa masa depan saya' kelak. Dalam kondisi yang rentan ini, Ikhwan berpendapat bahwa anak muda sedang mengalami 'kepanikan moral' (moral panic). ${ }^{57}$ Hal tersebut membuat mereka sangat agresif mencari jalan keluar, di antaranya mencari solusi di internet atau medsos. Di ruang online, ketika mereka sudah menemukan kenyamanan, mereka akan mudah menerima semua masukan yang mengubah cara berpikir, karakter, dan tindakannya. Dalam proses pencarian ini, tidak sedikit anak muda yang masuk ke dalam arena yang berbahaya, seperti Nurdhania yang berkenalan dengan Diary of $A$ Mubajirah, sebuah akun Facebook corong ISIS. Melalui laman blog pribadinya, Nurdahania sendiri mengakui bahwa dirinya berada pada kondisi kepanikan moral, yang kemudian membuatnya terdorong untuk bergabung dengan kelompok ekstrimisme atau ISIS.

Menurut Allport, anak muda sangat rentan dengan situasi di mana dirinya merasa khawatir, takut, dan cemas. ${ }^{58}$ Kecemasan dalam diri anak muda sering dilarikan ke medsos. Anak muda, terutama Gen Z, sangat dekat dengan gadgetnya. Bila ia cemas, cara yang tepat untuk mengobatinya ialah dengan berselancar di jagad medsos. Untuk memahami bagaimana siklus karakter dan keperibadianya Gen Z, penting untuk mengenal ciri-ciri fase kehidupan remaja yang disipulkan oleh Allport, yaitu pemekaran diri (extention of the self), kemampuan untuk melihat diri sendiri secara objektif (self objectivication), dan memiliki falsafah hidup tertentu (unifying philosophy of life). ${ }^{59}$

Sebelum Nurdhania tertarik dengan Timur Tengah, ia memiliki mimpi pergi ke United Kingdom (UK) untuk pertukaran pelajar (student exchange). Namun, ketika ia mulai tertarik dengan Timur Tengah, perhatiannya pun mulai berubah arah. Ia mengatakan

\footnotetext{
56 Ibid.

${ }^{57}$ Ikhwan, "Produksi Wacana Islam", 66.

${ }^{58}$ Nisa, "Generasi Z", 3.

${ }^{59} \mathrm{Ibid}$.
} 
"otak gue pikirannya udah mulai Timur Tengah gitu, terus gak jadi deh ikut student exchange-nya". Diceritakan, dalam pengalaman perjalanannya ke Syria, terutama ketika tiba di Turki, ia mulai merasakan warna-warni hidup di negeri orang. ${ }^{60}$ Ia mulai merasakan keindahan hidup di negara orang yang $360 \%$ berbeda dengan Indonesia, mulai kepercayaan, budaya, gaya hidup, suku, dan turis dari berbagai mancanegara. Kesenangan lain Nurdhania ketika bertemu dengan orang dari negara lain adalah bisa berbahasa Inggris. ${ }^{61}$ Beberapa pengalaman tersebut membuat ia semakin ingin cepat sampai ke Syria, meskipun pada akhirnya, setelah sampai di Syria, kenyataan berbicara lain. Ia merasa tertipu dengan propaganda dan janji-janji ISIS dahulu, lewat pengelola akun Diary of A Mubajirah, yang tidak sesuai dengan kenyataan yang ada.

\section{Ruang Hijrah dan Tempat Pelarian}

Masa transisi era Orde Baru ke Reformasi membuka jalan baru para aktor keagamaan, khususnya Islam, untuk tampil ke ruang publik. ${ }^{62}$ Menyuarakan kebebasan berpendapat di ruang publik tidak terlepas dari apresiasi pemerintah atas demokratisasi pascaOrde Baru. ${ }^{63}$ Meski belum dikatakan ideal, demokrasi di Indonesia setelah berakhirnya kepemimpinan Orde Baru telah membuka ruang-ruang debat publik, ${ }^{64}$ kontestasi keagamaan, ${ }^{65}$ dan pencarian legalitas suara publik. ${ }^{66} \mathrm{Iklim}$ demokrasi yang menopang kebebasan

\footnotetext{
${ }^{60}$ https://shiningsooul.wordpress.com/2019/07/02/warna-warni-hidup/.

${ }^{61}$ Lihat https://shiningsooul.wordpress.com/2019/07/02/warna-warni-hidup/; https://www.ruangobrol.id/2019/11/27/fenomena/perdamaian/returneesjuga-pernah-galau/. Diakses pada 13 Juli 2019.

62 Azyumardi Azra, "Globalization of Indonesian Muslim Discourse: Contemporary Religio-Intellectual Connections between Indonesia and the Middle East", dalam Johan Meuleman, Islam in the Era of Globalization: Muslim Attitudes towards Modernity and Identity (London and New York: Routledge, 2002); C.W. Watson, "Islamic Books and Their Publishers: Notes on the Contemporary Indonesian Scene”, Journal of Islamic Studies, Vol. 16, No. 2 (2005), 177-210.

63 Azra, "Globalisation of Indonesian Muslim Discourse".

${ }^{64}$ Ahmad Rafiq, "Dinamika Literatur Islamis di Ranah Lokal", dalam Hasan et al., Literatur Keislaman, 173-208.

${ }^{65}$ Dony Arung Triantoro, "Ustaz Abdul Somad: Otoritas Karismatik dan Media Baru” (Tesis--UIN Sunan Kalijaga Yogyakarta, 2019); Aflahal Misbah, "Fashion dalam Konstruksi Otoritas Ulama: Pandangan Kiai Shalih Darat", Jurnal Kajian Islam Interdisipliner, Vol. 3, No. 1 (2018), 61-84.

${ }^{66}$ Hasan, "Menuju Islamisme Populer".
} 
berekspresi tersebut telah digunakan oleh aktor-aktor Islam untuk mempengaruhi masyarakat Islam untuk hidup dalam bingkai keagamaan yang utuh $(k a ̈ f f a h) .{ }^{67}$

Secara perlahan, aktor Islam mulai mempengaruhi cara berpikir Gen Z dalam menerapkan hidup sesuai ajaran Islam, ${ }^{68}$ termasuk menciptakan kepanikan moral bagi mereka dalam memandang budaya Barat sebagai perusak tatanan nilai-nilai Islam. ${ }^{69}$ Publik yang penuh dengan kehidupan sekuler dan konsep-konsep liberal Barat yang seringkali dianggap bertentangan dengan ajaran Islam menjadi klaim untuk mengajak Gen Z kembali ke masa Islam klasik, yaitu masa tiga generasi Islam pertama (manhaj salafi) yang diyakini akan menyelamatkan hidup mereka dari situasi global yang penuh dengan kekafiran, kejahiliyahan, dan kesyirikan. Bentuk negara Islam kemudian diajukan sebagai solusi yang tepat untuk mewujudkan negara yang ideal. $^{70}$ Dalam pandangan teori Islamisme, hal tersebut merupakan cara yang tepat untuk menggantikan sistem pemerintahan yang bersih dari sekularisme, kekafiran, dan kesesatan. ${ }^{71}$

Narasi-narasi tersebut dipergunakan kelompok Islam ekstrem, seperti Negara Islam Indonesia (NII), Jemaah Islamiyah (JI), dan Jamaah Anshorut Daulah (JAD) untuk merekrut pejuang asing (foreign fighter) baru ISIS. $^{72}$ Kelompok remaja atau Gen Z merupakan sasaran yang tepat untuk menanamkan doktrin ideologi jihadis secara kontinyu. Selain mudah untuk dipengaruhi, Gen Z juga merupakan pemegang estafet perjuangan dakwah. Pada 1990an, di mana pasukan pemuda Laskar Jihad berkumpul di Senayan, Jakarta menyuarakan seruan tauhid, takbir, dan menyatakan sikap berjihad melawan musuh Islam, merupakan keberhasilan tersendiri

\footnotetext{
${ }^{67}$ Rafiq, "Dinamika Literatur Islamis".

${ }^{68}$ Kirana Nur Lyansari, "Hijrah Celebrity Creating New Religiosities, Branding Economics of Lifestyle in the Age of Muslim Mass Consumption", Analisis: Jurnal Studi Keislaman, Vol. 18, No. 2 (2018), 211-232.

69 Najib Kailani, "Forum Lingkar Pena and Muslim Youth in Contemporary Indonesia", RIMA: Review of Indonesian and Malaysian Affairs, Vol. 46, No. 1 (2012), 33-53.

${ }^{70}$ Hasan, "Menuju Islamisme Populer".

${ }^{71}$ Ibid.

72 IPAC "The Evolution of ISIS"; "The Surabaya Bombing's"; dan IPAC No. 56, “The Ongoing Problem of Pro-ISIS Cells in Indonesia” (2019): 1-19.
} 
bagi kelompok Islam ekstremis. ${ }^{73}$ Demikian halnya yang terjadi pada Nurdhania, yang sedang berada dalam proses pencarian jati diri dan rentan mengalami kepanikan moral. Ia menerima agama sebagai ketetapan yang sudah final. Klaim ajaran agama Diary of $A$ Mubajirab tidak bisa ditolak, sebagaimana pandangannya tentang hegemoni Barat yang sekuler membuat Nurdhania semakin menerima ideologi ISIS.

Penggunaan teknologi digital mempercepat akselerasi penyebaran informasi, berbeda dengan media lama seperti papirus, kertas, dan mesin ketik yang memerlukan waktu lama bagi sampainya pesan ke tangan pengguna. ${ }^{74} \mathrm{Hal}$ tersebut dapat dipahami, mengingat karakteristik teknologi digital adalah mempercepat pergerakan manusia dan memungkinkan dihasilkannya praktik-praktik baru dalam kehidupan manusia. ${ }^{75}$ Teknologi memang lahir dari kebutuhan masyarakat, yaitu adanya praktikpraktik sosial yang mendorong terciptanya teknologi baru. Williams menggambarkan kehidupan manusia yang terus berubah seiring dengan temuan hasil teknologi terbaru dengan istilah mobility (bergerak) dan transfer (pindah); lahirnya teknologi adalah akibat dari mobilitas hidup manusia yang senantiasa dinamis; teknologi sebagai mediation (perantara) mempercepat konektivitas manusia antara satu tempat ke tempat lain, satu ruang ke ruang lain. $^{76}$

Kehadiran teknologi mengalihkan perhatian masyarakat dari ruang offline ke online. Kehadiran internet mengubah pola konsumsi masyarakat Indonesia, termasuk konsumsi literatur keagamaan anak muda Gen Z. Sebelum adanya internet dan media sosial, mereka mengakses bacaan-bacaan literatur keislaman populer melalui buku, majalah, artikel, atau datang ke tempat-tempat pengajian keagamaan di majelis-majelis taklim. ${ }^{77}$ Namun, kehadiran

\footnotetext{
73 Ikhwan, "Produksi Wacana Islam", 77.

${ }^{74}$ Harold A. Innis, Empire and Communications (Victoria: Press Porcepic, 1986), 5.

75 Williams, Television.

76 Ibid.

77 Suhadi, "Menuju Bacaan Pendiddikan"; Kailani, "Forum Lingkar Pena"; Hasan, "Menuju Islamisme Populer"; Ikhwan, "Produksi Wacana Islam"; Rafiq, "Dinamika Literatur Islamis"; Monika Arnez dan Eva F. Nisa. “Dimensions of Morality: The Transnational Writers' Collective Forum Lingkar Pena", Journal of the Humanities and Social Sciences of Southeast Asia, Vol. 172, No. 4 (2016), 449-478.
} 
internet dan medsos membuat mereka berimigrasi ke dunia baru (maya) yang dianggap lebih instan, simpel, dan mudah diakses di manapun mereka berada. Internet dan fasilitas medsos dijadikan sebagai tools pencarian informasi agama. ${ }^{78}$

Kondisi tersebut mendorong aktor Islam untuk berkompetisi dan berkontesatasi menyebarkan pemahaman ideologi keagamaan masing-masing di ruang online. Aktor-aktor Islam mulai mewarnai aktivitas Islam di ruang online, terutama kelompok-kelompok jihadis yang begitu agersif melakukan propaganda tentang wajibnya Muslim Gen Z untuk jihad dan hijrah. Mereka menggunakan slogan-slogan yang provokatif dengan pola yang tetap. Sloganslogan tersebut berisi tentang Barat adalah musuh Islam dan oleh karenanya Islam ditindas dan dihancurkan; dan budaya Barat merusak kehidupan umat Islam, sehingga wajib hukumnya umat Muslim untuk jihad berperang di jalan Allah.

Lasswell mengatakan media memiliki dampak yang kuat (seringue bypodermique) terhadap respons audien sebagai objek. ${ }^{79}$ Begitu juga propaganda media jihadis berdampak langsung kepada pengikutnya, terutama pesan atau propaganda yang melibatkan psikologi manusia yang mudah tersentuh. Dalam teori psikologi, individu sangat mudah dipengaruhi untuk melakukan sesuatu. ${ }^{80}$ Teori perilaku (behavior) Watson menjelaskan bahwa manusia memiliki kesadaran, pikiran, dan imajinasi untuk melakukan sesuatu. ${ }^{81}$ Pikiran dan keinginan manusia juga dapat didorong melalui rangsangan dari orang lain, termasuk di antaranya doktrinasi ideologi jihadis. Model teori efek media Lasswell bisa dijadikan sebagai pijakan untuk melihat situasi agresif propaganda ISIS di medsos. Lasswell mengemukakan lima rantai proses siklus efek media yang bisa menjelaskan wacana pembentukan kebenaran dan penerimaan propaganda ISIS di medsos. Kebenaran dalam media bukan soal hakikat nilai kebaikan, tetapi soal penyebaran

\footnotetext{
${ }^{78}$ Nisa, “Generasi Z”.

79 Harold D. Lasswell, Propaganda Technique in World War 1 (Cambridge, MA: MIT Press, 1971a).

${ }^{80}$ John. B. Watson, Psychology From the Standpoint of A Behaviorist (Philadelphia: Lippincott, 1919).

81 Ibid.
} 
dan penerimaan seseorang terhadap pesan yang disampaikan. ${ }^{82}$ Lima tahapan proses siklus tersebut adalah sebagai berikut: ${ }^{83}$

Who
(Sender)

Lima siklus efek media Lasswell di atas menjelaskan mulai tentang siapa (who) yang memproduksi sampai dampak yang ditimbulkan (with what effect) kepada penerimanya. Siklus ini berlaku pada apa yang telah dijalankan oleh berbagai aktor Islam, termasuk aktor jihadis, untuk menguasai wacana keagamaan di ruang publik online. Walaupun banyak situs dan akun telah dihapus oleh Google, tetapi tetap saja penyebaran ideologi ISIS masih masif dilakukan. Menurut survei penelitian PSBPS (Pusuat Studi Budaya dan Perubahan Sosial) terhadap tiga situs keislaman (meliputi situs organisasi Islam arus utama, generasi Islam kontemporer, dan organisasi Islam non-afiliasi), ditemukan bahwa situs organisasi Islam non-afiliasi adalah yang paling banyak dikunjungi oleh warganet. ${ }^{84}$ Situs ini kerap kali dijadikan referensi hijrah anak muda Indonesia ke arah hidup yang lebih baik.

\section{Penutup}

Dari berbagai penjelasan di atas, dapat disimpulkan bahwa ketertarikan Nurdhania hijrah, berangkat ke Syria dan bergabung sebagai foreign fighter ISIS disebabkan oleh doktrin ISIS yang amat kuat, didukung dengan dalil al-Qur'ān dan Ḥadìth, janji-janji jaminan hidup yang amat menyakinkan, dan modus-modus lainnya, yang semua itu disuguhkan online lewat medsos berupa Facebook. Alhasil, melalui pertemanan online dengan akun Fecebook Diary of A Mubajirah, sebuah akun penyebar ideologi ekstremis-jihadis ISIS, Nurdhania terobsesi pada janji ISIS tentang "surga", yaitu hidup sejahtera di negeri yang diberkati (blessed land).

Lewat akun tersebut, propaganda ISIS adalah tentang penggantian uang keluarga Nurdhania, tempat tinggal, layanan kesehatan, akses pendidikan, dan listrik dan air yang bisa diperoleh secara gratis. ISIS menjanjikan kebahagiaan hidup setiap warganya

\footnotetext{
82 Syahputra, Hoaks dan Spiral Kebencian.

83 Harold D. Lasswell, "The Structure and Function of Communication in Society", The Communication of Ideas, Vol. 37, No. 1 (1948), 136-39.

${ }^{84}$ Situs non-afiliasi ialah situs Islam yang banyak memproduksi pesan-pesan keagamaan dalam narasi-narasi yang mendukung sikap dan tindakan radikalisme. Situs seperti ini dianggap mempengaruhi Gen Z dengan narasi ekstremisme.
} 
dan jaminan surga di dunia dan akhirat, meskipun setelah disadari pada akhirnya, semua itu jauh panggang dari api; Nurdhania melihat lingkungan yang tidak bersih, asrama yang kotor, perlakuan tidak baik, hujan hujatan, kejahatan, dan tipuan; tidak sedikit dari perempuan ISIS cekcok, saling melempar pisau, bahkan saling membunuh; kaum perempuan diwajibkan untuk menikah dengan para mujahid ISIS dan menjalani aksi militer, seperti mengoperasikan senjata AK-47 dan geranat berpeluncur roket.

Sebagai anak muda Gen Z, Nurdhania amat dekat dengan medsos, yaitu media tempat ia belajar (termasuk belajar Islam), mencari solusi, mengekspresikan segala emosi, bahkan mencurahkan 'kepanikan moral'-nya sebagai anak muda prempuan. Medsos memiliki pengaruh kuat dan langsung terhadap Gen Z; tidak hanya pada tataran wacana, tetapi juga aksi nyata. Kelompok ekstremis sadar betul akan kondisi tersebut. Oleh karena itu, mereka mengambil peluang untuk menyebarkan ideologinya secara online lewat medsos, dengan sasaran utamanya adalah anak muda Gen Z, yang tak lain adalah pengguna aktif medsos; rentan mengalami kepanikan moral; mudah dipengaruhi; dan bisa menjadi pemegang estafet ideologi ekstremis di masa depan. Kondisi ini perlu menjadi perhatian berbagai pihak, terutama mereka yang terkait langsung dengan upaya memutus mata rantai radikalisme di tengah masyarakat, khususnya di kalangan anak muda.

\section{Daftar Rujukan}

Arnez, Monika dan Eva F. Nisa. "Dimensions of Morality: The Transnational Writers' Collective Forum Lingkar Pena”, Journal of the Humanities and Social Sciences of Southeast Asia, Vol. 172, No. 4, 2016.

Azra, Azyumardi. "Globalization of Indonesian Muslim Discourse:

Contemporary Religio-Intellectual Connections between Indonesia and the Middle East", dalam Johan Meuleman, Islam in the Era of Globalization: Muslim Attitudes towards Modernity and Identity. London and New York: Routledge, 2002.

Broadbent, Emma. Generation Z: Global Citizenship Survey. London: Varkey Fundation, 2017.

Campbell, Heidi A. (ed.). Digital Religion: Understanding Religious Practice in New Media Worlds. London: Routledge, 2013.

Gow, James et al. (eds.). Militancy and Violence in West Africa: Religion, Politics, and Radicalisation. London: Routledge, 2013. 
Hasan, Noorhaidi. "Gagalnya Jihadisme di Kalangan Generasi Milenial", dalam Noorhaidi Hasan et al., Literatur Keisalaman Generasi Milenial: Transmisi, Apropriasi, dan Kontestasi. Yogyakarta: UIN Sunan Kalijaga Perss 2018.

-----. "Menuju Islamisme Populer", dalam Noorhaidi Hasan et al., Literatur Keisalaman Generasi Milenial: Transmisi, Apropriasi, dan Kontestasi. Yogyakarta: UIN Sunan Kalijaga Perss 2018.

Hélie, Anissa. "The US Occupation and Rising Religious Extremism: The Double Threat to Women in Iraq", Znet, 24 Juni 2005, http://www.zcommunications.org/the-u-soccupation-and-rising-religious-extremism-by-anissa-h-lie.

Herrera, Linda dan Asef Bayat (eds.). Being Young and Muslim: New Cultural Politics in the Global South and North. Oxford: Oxford University Press, 2010.

Howard, Robert Glenn. "Enacting a Virtual 'Ekklesia': Online Christian Fundamentalism as Vernacular Religion", New Media \& Society, Vol. 12, No. 5, 2010.

https://id.m.wikipedia.org/wiki/GenerasiZ. Diakses pada 13 Juli 2019.

https://m.facebook.com/groups/251751038294937?view=permal ink \&id $=538586862944685$. Diakses pada 10 Juli 2019.

https://shiningsooul.wordpress.com/2019/07/02/warna-warnihidup/.

https://www.google.com/amp/s/amp.kompas.com/tekno/read/ 2014/11/24/07430087/Pengguna.Internet.Indonesia.Nomor. Enam.Dunia.

https://www.ruangobrol.id/2019/11/21/ulasan/analisa/pengala man-returnees-kena-doktrinisasi-kelompok-ekstrimis/. 13 Juli 2019.

https://www.ruangobrol.id/2019/11/27/fenomena/perdamaian/ retur nees-juga-pernah-galau/. Diakses 13 Juli 2019.

https://youtu.be/4Cm-b9lkyec. Diakses pada 13 Juli 2019. https://youtu.be/DJ7lxI4YcfY. Diakses pada 12 Juli 2019. Ikhwan, Munirul. "Produksi Wacana Islam di Indonesia: Revitalisasi Islam Publik dan Politik Muslim", dalam Noorhaidi Hasan et al., Literatur Keisalaman Generasi Milenial: Transmisi, Apropriasi, dan Kontestasi. Yogyakarta: UIN Sunan Kalijaga Perss 2018. 
Innis, Harold A. Empire and Communications. Victoria: Press Porcepic, 1986.

Ismail, Noor Huda. "The Role of Kinship in Indonesia's Jemaah Islamiya”, Terrorism Monitor, Vol. 4, No. 11, 2006.

Kailani, Najib. "Forum Lingkar Pena and Muslim Youth in Contemporary Indonesia", RIMA: Review of Indonesian and Malaysian Affairs, Vol. 46, No. 1, 2012.

King, Michael dan Donald M. Taylor. "The Radicalization of Homegrown Jihadists: A Review of Theoretical Models and Social Psychological Evidence", Terrorism and Political Violence, Vol. 23, No. 4, 2011.

Knop, Katharina Von. “The Female Jihad: Al Qaeda's Women”, Studies in Conflict \& Terrorism, Vol. 30, No. 5, 2017.

Laporan ICG (International Crisis Group) No. 83. "Indonesia Backgrounder: Why Salafism and Terrorism Mostly Adon't Mix". 2004.

Laporan IPAC No. 13, "The Evolution of ISIS in Indonesia", 2014.

Laporan IPAC No. 35. "Mother to Bombers: The Evolution of Indonesia Woman Extremists". 2017.

Laporan IPAC No. 39. "The Radicalisation of Indonesian Woman Workers in Hong Kong”. 2017.

Laporan IPAC No. 47. "Managing Indoneaia's Pro-ISIS Deportees", 2018.

Laporan IPAC No. 51. "The Surabaya Bombing's and the Future of ISIS in Indonesia". 2018.

Laporan IPAC No. 56. "The Ongoing Problem of Pro-ISIS Cells in Indonesia". 2019.

Lasswell, Harold D. "The Structure and Function of Communication in Society", The Communication of Ideas, Vol. 37, No. 1, 1948.

-----. Propaganda Technique in World War 1. Cambridge, MA: MIT Press, 1971a.

Lyansari, Kirana Nur. "Hijrah Celebrity Creating New Religiosities, Branding Economics of Lifestyle in the Age of Muslim Mass Consumption", Analisis: Jurnal Studi Keislaman, Vol. 18, No. 2, 2018. 
Maulana, Dirga. Situs-situs Islam: Konstestasi Narasi Radikal dan Moderat, Vol. 1, No. 3. Jakarta: PPIM UIN Syarif Hidayatullah Jakarta, 2018.

McLuhan, Marshall. Understanding Media. New York: McGraw-Hill, 1965.

Misbah, Aflahal. "Fashion dalam Konstruksi Otoritas Ulama: Pandangan Kiai Shalih Darat", Jurnal Kajian Islam Interdisipliner, Vol. 3, No. 1, 2018.

Nelly, Lahoud. "The Neglected Sex: The Jihadis' Exclusion of Women From Jihad", Terrorism and Political Violence, Vol. 26, No. 5, 2014.

Nisa, Yunita Faela. "Generasi Z: Generasi yang Galau", dalam Didin Syafruddin dan Ismatu Ropi (eds.), Generasi Z: Kegalauan Identitas Keagamaan. Jakarta: PPIM-UIN Jakarta, 2018.

Nuraniyah, Nava. "Not Just Brainwashed: Understanding the Radicalization of Indonesian Female Supporters of the Islamic State", Terrorism and Political Violence, Vol. 30, No. 6, 2018.

Piazza, James A. "Poverty, Minority Economic Discrimination, and Domestic Terrorism", Journal of Peace Research, Vol. 48, No. 3, 2011.

Qodir, Zuly. "Gerakan Salafi Radikal dalam Konteks Islam Indonesia: Tinjauan Sejarah", Islamica: Jurnal Studi Keislaman, Vol. 3, No. 1, 2008.

Rafiq, Ahmad. "Dinamika Literatur Islamis di Ranah Lokal", dalam Noorhaidi Hasan et al., Literatur Keisalaman Generasi Milenial: Transmisi, Apropriasi, dan Kontestasi. Yogyakarta: UIN Sunan Kalijaga Perss 2018.

Saikal, Amin. "Women and Jihad: Combating Violent Extremism and Developing New Approaches to Conflict Resolution in the Greater Middle East", Joumal of Muslim Minority Affairs, Vol. 36, No. 3, 2016.

Smit, Rosalie. "Defining Professionalism in anti-Islamic Radicalism Policies". Working Research Paper (Working in the Front-line of Society Amsterdam, 2009).

Suhadi. "Menu Bacaan Pendidikan Agama Islam", dalam Noorhaidi Hasan et al., Literatur Keisalaman Generasi Milenial: Transmisi, Apropriasi, dan Kontestasi. Yogyakarta: UIN Sunan Kalijaga Perss 2018. 
Sunarto, Andang. "Dampak Penyebaran Ideologi Ultrakonservatif di Media Sosial", Nuansa, Vol. 11, No. 2, 2017.

Supratman, Lucy Pujasari. "Penggunaan Media Sosial oleh Digital Native”, Ilmu Komonikasi, Vol. 15, No. 1, 2018.

Syahputra, Iswandi. Hoaks dan Spiral Kebencian di Media Sosial. Yogyakarta: UINSunan Kalijaga Yogyakarta, 2019.

Tighe, Evan. "Trust in Allah, But Tie Your Camel: The Effects of Radicalized Schooling and State Security on Islamic Terrorism in the Middle East". Disertasi--University of Georgia, Athens, 2011.

Triantoro, Dony Arung. "Ustaz Abdul Somad: Otoritas Karismatik dan Media Baru". Tesis--UIN Sunan Kalijaga Yogyakarta, 2019.

Watson, C.W. "Islamic Books and Their Publishers: Notes on the Contemporary Indonesian Scene", Journal of Islamic Studies, Vol. 16, No. 2, 2005.

Watson, John. B. Psychology From the Standpoint of A Behaviorist. Philadelphia: Lippincott, 1919.

Williams, Raymond. Television: Technology and Cultural Form. London: Routledge, 2003.

Young, G. "Reading and Praying Online: The Continuity of Religion Online and Online Religion in Internet Christianity", dalam L. Dawson and D. Cowan (eds.). Religion Online: Finding Faith on the Internet. New York: Routledge, 2004.

Zambelis, Chris. "Is there a Nexus between Torture and Radicalization?", Terrorism Monitor, Vol. 6, No. 13, 2008.

\section{Wawancara}

M. Raihan Rafisanjani. Wawancara. Yogyakarta, 2019. 